EESTI NSV TEADUSTE AKADEEMIA TOIMETISED, 25. KOIDE KEEMIA * GEOLOOGIA. 1976, Nr. 3

ИЗВЕСТИЯ АКАДЕМИИ НАУК ЭСТОНСКОИ ССР. ТОМ 25 ХИМИЯ * ГЕОЛОГИЯ. 1976, № 3

К. ЛЭЭТС, Х. РАНГ, В. ЧЕРНЫШОВ, Ильме КАЛЬЯ,

М. КОЭЛЬ

\title{
О РЕАКЦИИ ПРИСОЕДИНЕНИЯ 2-ХЛОР-3-ПЕНТЕНА К ХЛОРПРОИЗВОДНЫМ ЭТЕНА
}

K. LÃTS, H. RANG, V. TSERNOSOV, ILME KALJA, M. KOEL. 2-KLOOR-3-PENTEENI JA ETEENI KLOORDERIVAATIDE OHINEMISREAKTSIOONIST

K. LÄATS, H.RANG, V. TSHERNYSHOV, ILME KALJA, M. KOEL. ABOUT REACTIONS WITH 2-CHLORO-3-PENTENE AND CHLORODERIVATES OF ETHENE

Данные о присоединении аллильных хлоридов к хлоралкенам в литературе отсутствуют. Реакции, протекающие между 2-хлор-3-пентеном и хлоралкенами (хлорпроизводные этена) в присутствии катализаторов $\mathrm{SnCl}_{4}$ и $\mathrm{AlCl}_{3}$, изучены нами с помощью капиллярной хроматографии высших галогенпроизводных аллильного типа ['] и спектроскопии ПМР.

Характеристика реакции теломеризации 2-хлор-3-пентена $\left(\mathrm{C}_{5} \mathrm{H}_{9} \mathrm{Cl}\right)$ с хлорэтеном $\left(\mathrm{C}_{2} \mathrm{H}_{3} \mathrm{Cl}\right)$

\begin{tabular}{c|c|c|c}
\hline \multicolumn{2}{c|}{ Молярное соотношение } & $\begin{array}{c}\text { Степень } \\
\text { конверсии, } \\
\%\end{array}$ & $\begin{array}{c}\text { Содержание } \\
\text { первого аддук- } \\
\text { та } \mathrm{C}_{7} \mathrm{H}_{12} \mathrm{Cl}_{2} \text { в } \\
\text { теломере, \% }\end{array}$ \\
\hline $\begin{array}{c}\mathrm{C}_{2} \mathrm{H}_{3} \mathrm{Cl} \\
\mathrm{C}_{5} \mathrm{H}_{9} \mathrm{Cl}\end{array}$ & $\frac{\text { катализатор }}{\mathrm{C}_{5} \mathrm{H}_{9} \mathrm{Cl}} \cdot 10^{-2}$ & & \\
\hline & & 45,7 & 5,7 \\
1,0 & 44 & 16,5 & 7,0 \\
1,0 & 0,73 & 10,9 & 15,7 \\
0,5 & 2,0 & 11,6 & 20,8
\end{tabular}

Примечание. Катализатор $\mathrm{SnCl}_{4}$, температура реакции $0^{\circ}-1^{\circ} \pm 2^{\circ} \mathrm{C}$; время реакцин от 90 до 200 мин.

В случае 1,2-дихлор-, трихлор- и тетрахлорэтена изменения в составе исходных компонентов реакции (изменение плотности реакционной смеси) происходят только при больших $\left(2 \cdot 10^{-2}\right.$ г-моль/л) количествах катализатора $\mathrm{SnCl}_{4}$. При этом исходный 2 -хлор-3-пентен, судя по полученным газохроматографическим данным, подвергается димеризации, дегидрохлорированию и последующей теломеризации с образующимся 1,3-пентадиеном. В присутствии безводного $\mathrm{AlCl}_{3}$ образуется сложная смесь продуктов, которую не удалось идентифицировать. При теломеризации 2 -хлор-3-пентена с хлорэтеном в присутствии $\mathrm{SnCl}_{4}$ (таблица) получена смесь теломеров. Моноаддукт 1,1-дихлор-3-метил-4-гексен с т. кип. $52-53^{\circ} \mathrm{C} \quad(10 \mathrm{M \mu}), d_{4}^{20} 1,0312, n_{D}^{20} \quad 1,4598$. Спектр ПМР снят в виде $15 \%$-ного раствора $\mathrm{CCl}_{4}$ на спектрометре $\mathrm{ZKR} 60$ с рабочей частотой $60 \mathrm{M} Г$ ц ( $\delta$ м. д. относительно ТМС) : 1,03 Д $\left(\mathrm{CH}_{3}-\mathrm{C}-\right), 1,69$ Д $\left(\mathrm{CH}_{3}-\mathrm{C}=\right)$, 2,15 Д $\left(\mathrm{CH}_{2}\right), 2,2-2,4 \mathrm{M}(\mathrm{CH}), 5,25-5,80 \mathrm{M}(-\mathrm{CH}=)$ и $\left(-\mathrm{CHCl}_{2}\right)$. 


\title{
Л И Т Е Р Т У Р А
}

1. Эрм А. Ю., Калья И. А., Лээтс К. В., Изв. АН ЭССР, Хим. Геол., 21, 300 (1972).
Ннститут химии
Академии наук Эстонской ССР
Поступила в редакцию
$22 /$ VI 1975

\author{
EESTI NSV TEADUSTE AKADEEMIA TOIMETISED, 25. KOIDE \\ KEEMIA * GEOLOOGIA. 1976, Nr. 3 \\ ИЗВЕСТИЯ АКАДЕМИИ НАУК ЭСТОНСКОП ССР. ТОМ 25 \\ ХимИЯ * ГЕОЛОГИЯ. 1976, № 3
}

Х. ПАЛЬМРЕ

удК $550.42: 546$

\section{ЗАМЕТКИ О ВСТРЕЧАЕМОСТИ ИНДИЯ \\ В ПИРИТОВЫХ КРИСТАЛЛАХ ПАЛЕОЗОЙСКИХ ОТЛОЖЕНИИ ЭСТОНСКОЙ ССР}

\begin{abstract}
H. PALMRE, MARKMEID INDIUMI ESINEMISEST EESTI NSV PALEOSOIKUMI PORIIDIKRISTALLIDES

H. PALMRE. BEMERKUNGEN OBER DAS VORKOMMEN DES INDIUMS IN DEN PYRITKRISTALLEN DES PALAOZOIKUMS DER ESTNISCHEN SSR
\end{abstract}

Геохимические особенности индия изучались многими исследователями (Боровик и др., 1939; Иванов, Волгин, 1960; Иванов, 1960, 1966 ; Andreson, 1953; Shaw, 1957; и др.). Содержание индия в земной коре обычно невелико и весьма непостоянно - его кларк составляет 0,14 2/T (Иванов, 1966). Характерной особенностью индия, по В. В. Иванову $(1964,1966)$, является его участие в гидротермальном сульфидном процессе, где он тесно связан главным образом с оловом. Основное количество индия в природе встречается в виде изоморфной примеси в минералах других элементов.

О встречаемости индия в пиритовых кристаллах палеозойских отложений Эстонской ССР в настоящее время имеется очень мало сведений. В сообщении приведены данные о характере распространения индия в пиритовых кристаллах, возникших в ходе диагенеза в нижнекембрийских, ордовикских и силурийских отложениях, а также в пиритах, встречающихся в гидротермальных свинцово-цинковых рудопроявлениях карбонатных пород Эстонской ССР.

Образцы сульфидных минералов отбирались по профилям обнажений с учетом геологического положения и характера вмещающих пород. Определение индия проводилось в лаборатории Таллинского политехнического института на кафедре аналитической химии Х. Хедреярв по ее же методу (Хедреярв, 1967).

При сопоставлении данных о содержании индия в пиритовых кристаллах, собранных нами из разных горизонтов кембрия, ордовика и силура и из разной литологической среды, выясняются особенности концентрации индия в сульфидных образованиях железа (таблица). 